\title{
PEMANTAUAN KUALITAS AIR ONLINE DAN REALTIME DI INTAKE PDAM TAMAN KOTA CENGKARENG DRAIN DKI JAKARTA
}

\author{
Heru Dwi Wahjono \\ Pusat Teknologi Lingkungan, BPPTeknologi \\ Jl. M.H. Thamrin No. 8 Gd. II Lt. 18 Jakarta 10340
}

\begin{abstract}
The need for clean water in big cities is very dependent on water supply by water companies (PDAM). The increasing demand for clean water in big cities is proportional to the increasing of number population and industry, but not comparable to the clean water supply and quality of raw water available. PDAM has made various efforts to improve the quality of clean water services to the community. One of the effort is to improve the performance of water treatment plant (WTP). To support the improvement of the performance of WTP, required water quality monitoring at the intake location in use. This paper discusses the online and realtime water quality monitoring at the water intake location using a multi-probe digital sensor and GSM technology. This observation data is used as a comparative data analysis of laboratory data on raw water source PDAM Taman Kota (Cengkareng Drain).
\end{abstract}

Keywords: air baku air minum, intake PDAM Taman Kota Cengkareng Drain, pemantuan kualitas air, multi probe digital sensor, teknologi online monitoring, Water Treatment Plant

\section{PENDAHULUAN}

\subsection{Latar Belakang}

Kebutuhan air bersih di perkotaan khususnya kota-kota besar sangat bergantung kepada penyediaan air bersih oleh perusahaan air minum daerah (PDAM). Peningkatan kebutuhan air bersih di kota besar sebanding dengan peningkatan jumlah penduduk dan industri, akan tetapi produksinya tidak dapat mengimbangi kebutuhan yang meningkat terus. Sumber-sumber air yang ada sekarang tidak dapat digunakan sebagai air baku PDAM lagi karena kondisinya yang sudah tercemar berat.

Data indeks kualitas air sungai di DKI Jakarta pada bulan November 2004 menunjukkan semakin berkurangnya jumlah sungai dengan kualitas golongan B (air baku air minum) dan semakin meningkatnya jumlah sungai dengan kualitas golongan $C$ (perikanan dan peternakan) serta kualitas golongan $D$ (pertanian dan usaha perkotaan). Gambar 1 menunjukkan lokasi titik pantau yang dimiliki oleh BPLHD DKI Jakarta dengan status index kualitas airnya ${ }^{1)}$.

Untuk mengatasi permasalahan sumber air baku di wilayah DKI Jakarta, PDAM telah mengupayakan sumber lain yang berasal dari wilayah Jawa Barat. Dari data yang dikeluarkan oleh Palyja, sumber air baku yang digunakan oleh PDAM saat ini adalah $60 \%$ berasal dari saluran Tarum Barat, 35\% berasal dari sungai Cisadane dan $5 \%$ berasal dari sungai-sungai di wilayah DKI Jakarta 2). Gambar 2 menunjukkan peta sumber daya air baku yang dimiliki oleh Palyja sebagai perusahaan yang menyediakan air bersih di wilayah DKI Jakarta dan sekitarnya.

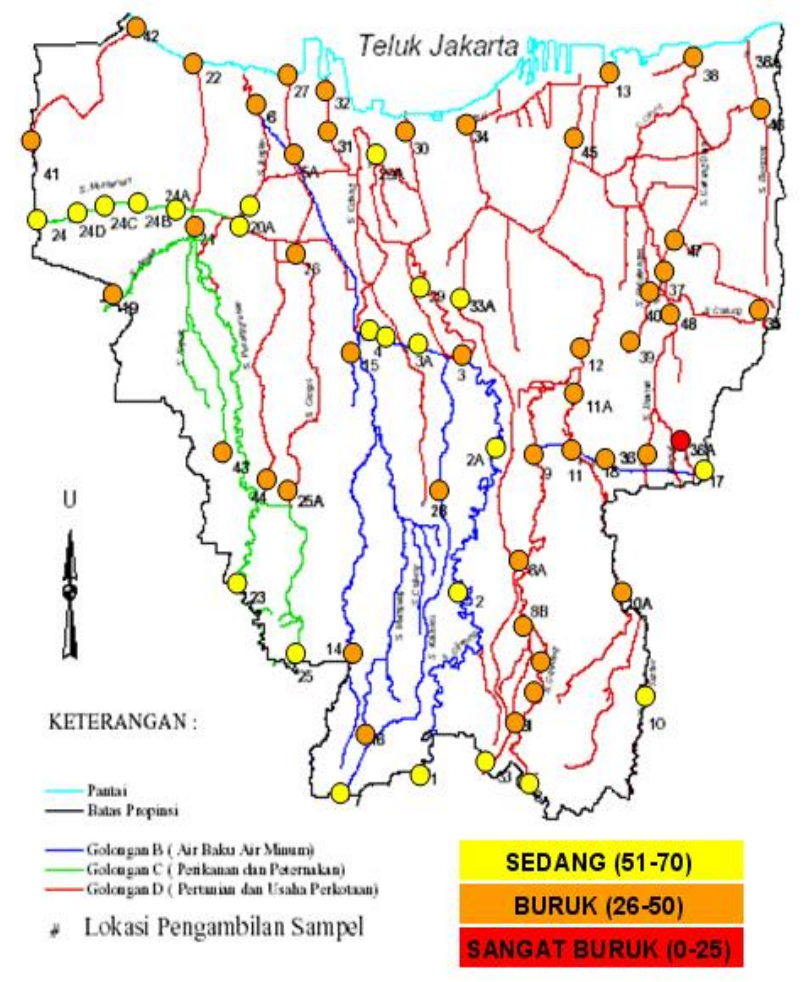

Gambar 1. Indeks Kualitas Air Sungai Jakarta

Selain mengupayakan sumber air baku dari lokasi lain, PDAM telah melakukan berbagai 


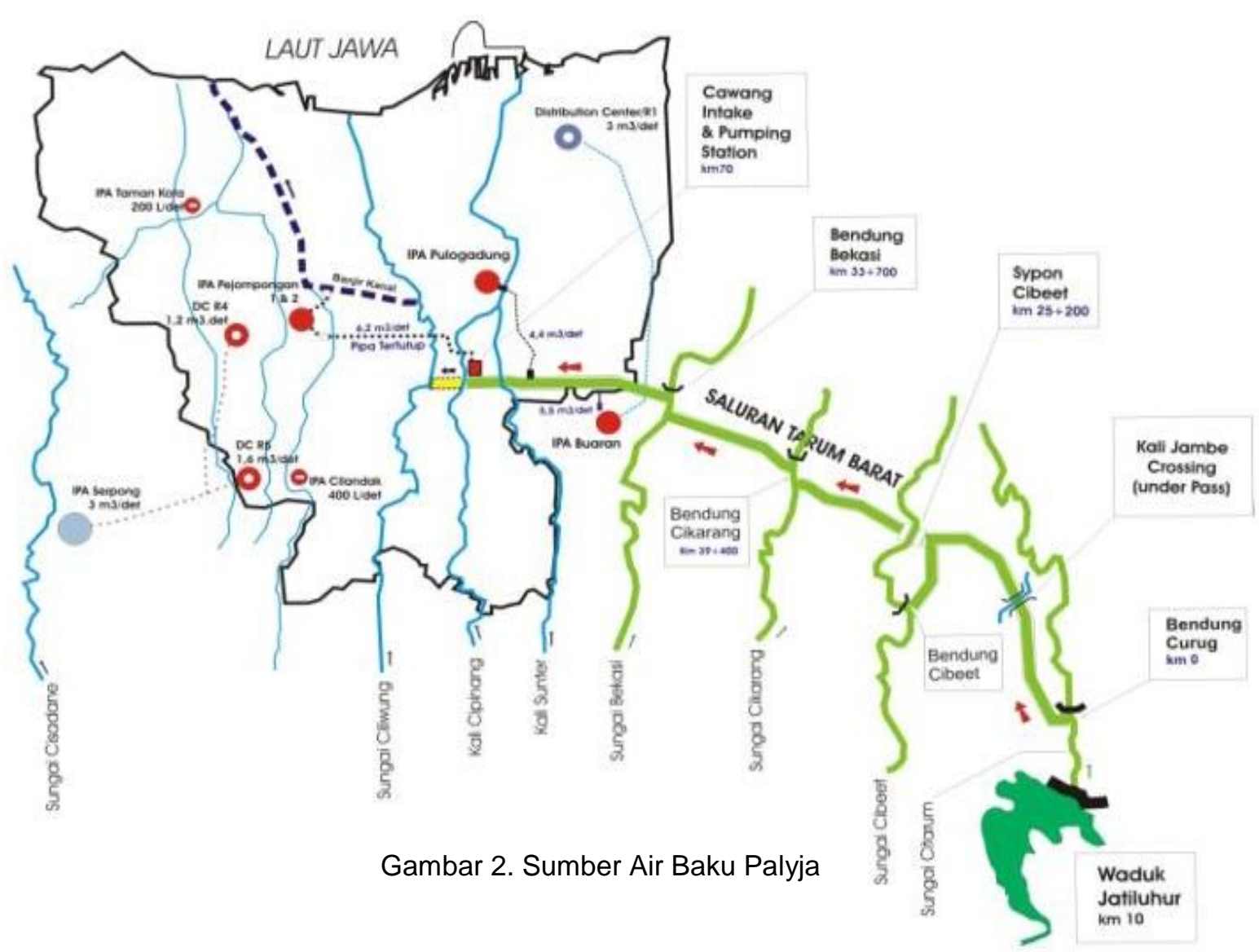

upaya untuk meningkatkan kualitas pelayanan air bersih kepada masyarakat, antara lain melakukan perbaikan teknologi untuk proses pengolahan air sesuai kualitas air baku yang ada dan memperbaiki kinerja Instalasi Pengolahan Air (IPA) yang ada. Selain itu, PDAM sedang melakukan penelitian untuk menerapkan teknologi biofilter guna mengantisipasi sumber air baku yang tercemar oleh limbah domestik perkotaan. Pencemaran oleh limbah domestik ini menyebabkan menurunnya kualitas air bersih yang dihasilkan oleh instalasi yang ada ${ }^{3)}$.

Untuk mendukung perbaikan kinerja instalasi pengolahan air dan penelitian tersebut dibutuhkan pemantauan kualitas air di lokasi intake yang digunakan oleh PDAM Taman Kota, yaitu di Cengkareng Drain, Jakarta Utara. Hasil pengamatan menggunakan sistem online monitoring ini dapat digunakan sebagai data pembanding dengan data analisa laboratorium.

\subsection{Tujuan Dan Sasaran}

Tujuan dari kegiatan pemantauan ini adalah untuk mendapatkan data kualitas air yaitu Temperatur, pH, DO, Konduktifitas, TDS dan Salinitas ${ }^{4)}$ di lokasi intake PDAM Taman Kota di Cengkareng Drain Jakarta Utara. Sedangkan sasarannya adalah mendapatkan data realtime keenam parameter kualitas air di atas setiap jamnya di hasil pengolahan reaktor biofilter.

\subsection{Metodologi}

Metodologi yang digunakan untuk melaksanakan kegiatan pemantauan kualitas air di lokasi pengamatan adalah sebagai berikut :

a. Survei lokasi, dilakukan dengan mengamati lokasi tempat pemasangan peralatan sistem online monitoring. Data yang diperlukan adalah lokasi penempatan sensor dan data logger serta teknis pengamanan peralatan di lapangan.

b. Persiapan peralatan, dilakukan dengan mempersiapkan peralatan monitoring, yaitu kalibrasi sensor $\mathrm{DO}$ dan $\mathrm{pH}$ dengan larutan standar, pengecekan rangkaian data logger serta pengisian pulsa pada GSM modem.

c. Pemasangan peralatan, dilakukan pada titik lokasi yang telah ditentukan dan dinilai aman untuk menempatkan sensor dan data logger. Sensor harus selalu tercelup ke dalam air sedangkan data logger dan GSM modem tidak boleh basah atau lembab karena air.

d. Pengamatan di pusat data, dilakukan dengan mengoperasikan software SMS gateway untuk mengendalikan data logger dan perangkat lunak database online monitoring. 


\subsection{Lokasi Pengamatan}

Data lokasi pengamatan :

- Nama Stasiun: Intake PDAM Taman Kota

- ID Stasiun : SB1

- Alamat Stasiun: Cengkareng Drain

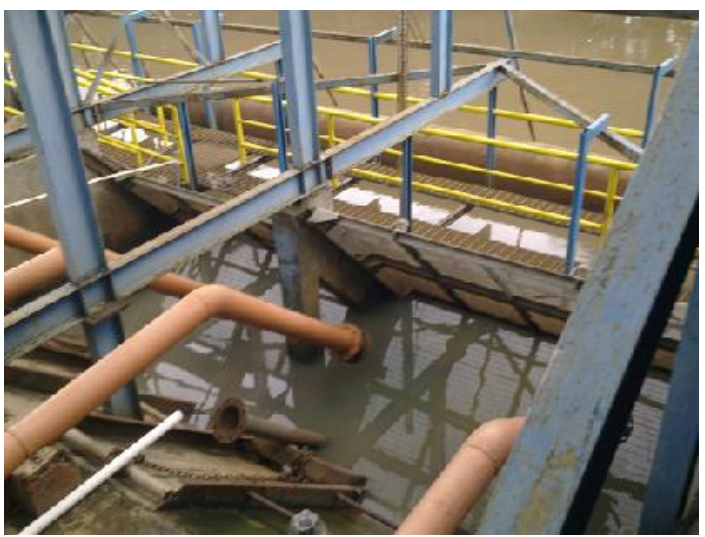

Gambar 3. Foto Intake PDAM Taman Kota di Cengakreng Drain

Pada lokasi intake PDAM Taman Kota telah diinstalasikan reaktor biofilter untuk mengolah air baku dari Cengkareng Drain. Gambar berikut adalah reaktor biofilter untuk mengolah air baku yang tercemar limbah domestik.

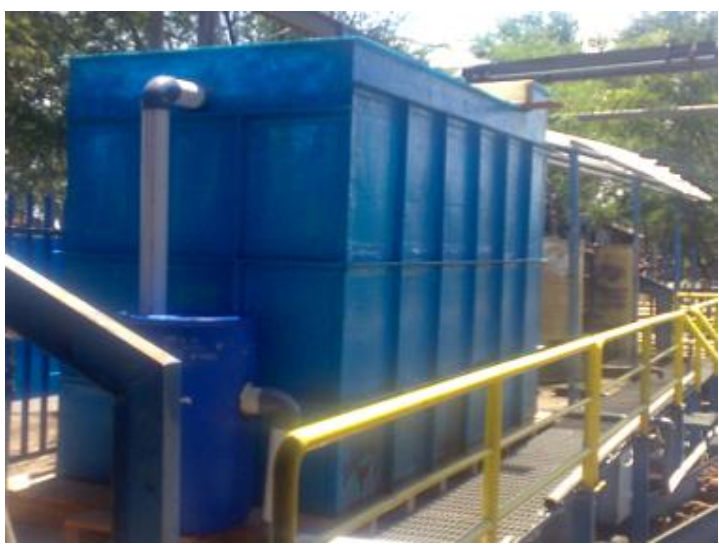

Gambar 4. Reaktor Biofitler Pengolahan Air

Unit sensor dipasang di dalam bak di bagian akhir proses pengolahan oleh reaktor biofilter tersebut. Sedangkan panel kontrol data logger ditempatkan di dekat reaktor biofilter tersebut dengan posisi yang aman dan tidak kena air limpasan olahan atau air hujan. Posisi antena di pasang di posisi paling tinggi di lokasi tersebut. Gambar 5 adalah sensor yang telah tercelup di dalam reaktor biofitler dan data logger yang telah terpasang.
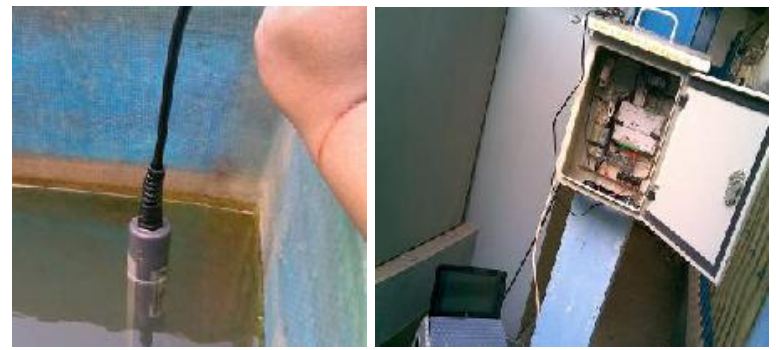

Gambar 5. Sensor dan Data Logger Yang Telah Terpasang di Lokasi Pengamatan

\section{Pemantauan Kualitas Air}

\subsection{Peralatan Monitoring}

Beberapa peralatan utama dan peralatan penunjang yang digunakan untuk pengamatan kualitas air baku adalah sebagai berikut :

a. Multi probe sensor digital kualitas air yang mampu mengukur 6 parameter kualitas air sekaligus, yaitu Temperatur, $\mathrm{pH}, \mathrm{DO}$, Konduktifitas, TDS, dan Salinitas ${ }^{4)}$.

b. Larutan standar $\mathrm{pH}$ 4, 7 dan 10 digunakan untuk melakukan kalibrasi sensor $\mathrm{pH}$. Larutan KCL digunakan untuk pemeliharaan sensor DO ${ }^{4}$.

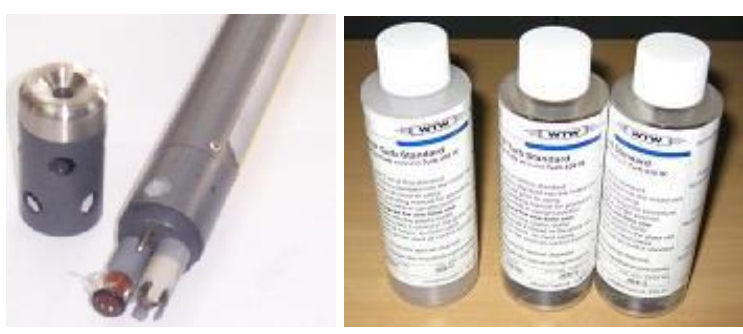

Gambar 6. Sensor Digital dan Larutan Standar Untuk Kalibrasi

c. Data Logger sebagai pengendali pengukuran kualitas air di stasiun pengamatan. Interval waktu pengukuran dalam data logger dapat diset sesuai kebutuhan ${ }^{5}$.

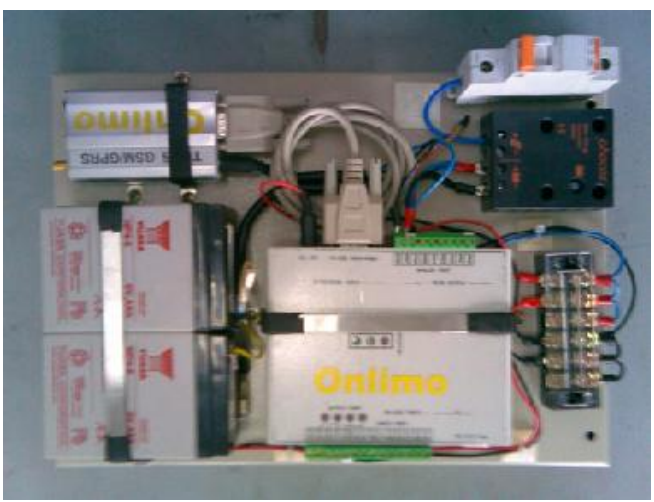

Gambar 7. Data Logger 
d. Software SMS Gateway digunakan sebagai pengendali pengiriman data melalui SMS dan software database onlimo sebagai sistem penyimpan dan penelusuran kembali data monitoring kualitas air ${ }^{5)}$.

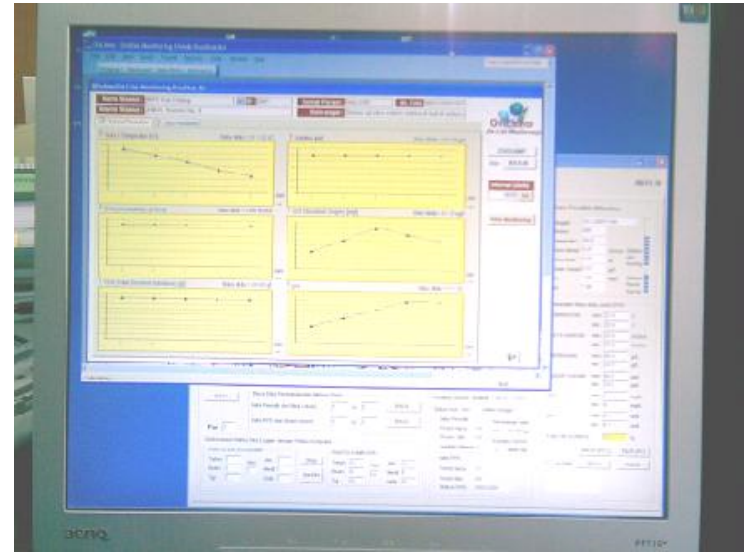

Gambar 8. SMS Gateway dan Database Onlimo

\subsection{Setting Konfigurasi}

Kegiatan pemantauan kualitas air di sumber air baku intake PDAM Taman Kota Cengkareng Drain Jakarta Utara dilaksanakan selama 4 bulan. Pengamatannya dilakukan secara otomatis menggunakan sistem online dan realtime dengan setting konfigurasi interval waktu pengukuran 1 jam sekali dan interval peringatan dini 60 detik. Sehingga dalam sehari akan diperoleh 24 data pengukuran kualitas air dan waktu keterlambatan peringatan dini adalah 60 detik. Lokasi pusat data adalah di BPPT Jakarta Pusat ${ }^{3)}$

Selain setting konfigurasi interval waktu pengukuran, dilakukan pula setting interval pengiriman data pengukuran dilakukan setiap 6 jam guna menghemat biaya SMS. Jadi dalam sehari ada 4 kali biaya transaksi pengiriman SMS berisi data pengukuran. Namun setiap saat Program Logic Control (PLC) di dalam data logger dapat mengirimkan data pengukurannya apabila hasil pengukurannya tidak memenuhi baku mutu yang telah ditentukan. Adapun baku mutu yang ditentukan dalam data logger adalah sebagai berikut : Temperatur : $20^{\circ} \mathrm{C} \sim 30^{\circ} \mathrm{C}$, Konduktifitas maksimal : $50 \mathrm{mS} / \mathrm{cm}$, TDS maksimal : $30 \mathrm{~g} / \mathrm{l}$, Salinitas maksimal : $30 \mathrm{ppt}$, DO minimal : $3 \mathrm{mg} / \mathrm{l}, \mathrm{pH}: 6 \sim 8^{5}$ )

\subsection{Pemeliharaan Sensor}

Kondisi air intake di Cengkareng Drain secara visual sangat keruh dan berwarna coklat. Sehingga perawatan sensor perlu dilakukan untuk mengoptimalkan hasil pengukuran kualitas air di lokasi. Perawatan dilakukan sebulan sekali dengan membersihkan permukaan sensor dari kotoran yang melekat di badan sensor dan mengganti membran plastik penutup permukaan sensor DO dengan memberikan larutan $\mathrm{KCl}$ terlebih dahulu. Gambar 9 menunjukkan probe sensor yang kotor dan perlu dibersihkan.

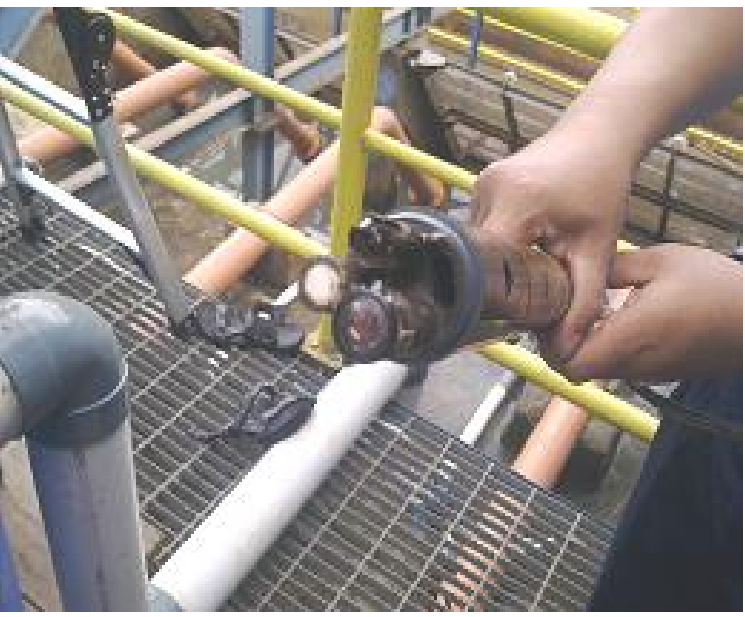

Gambar 9. Permukaan Sensor Yang Perlu Dibersihkan

Kegiatan perawatan sensor dilengkapi dengan proses kalibrasi ulang terhadap sensor DO yang memang pada kegiatan monitoring ini data pengukurannya menunjukkan beberapa anomali, sehingga diperlukan proses kalibrasi. Gambar 10 menunjukkan kegiatan kalibrasi sensor menggunakan laptop di lokasi stasiun monitoring.

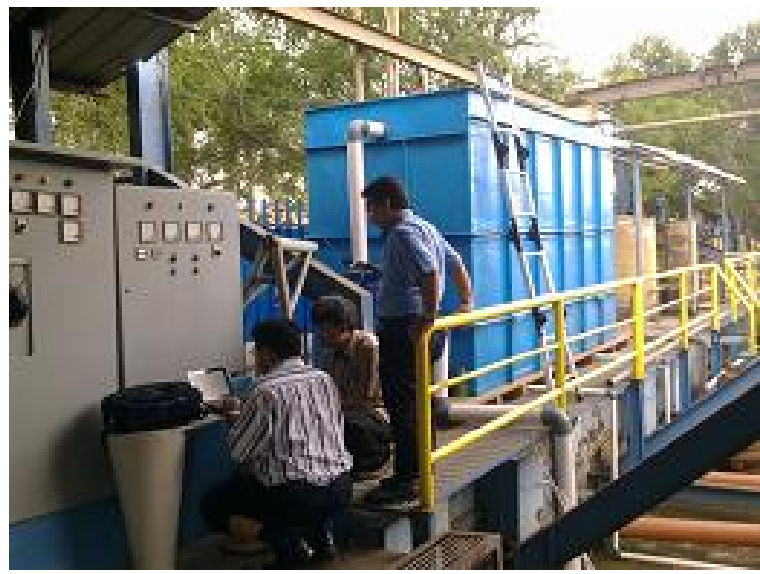

Gambar 10. Kalibrasi Sensor Menggunakan Laptop di Lokasi Stasiun Monitoring

\section{PEMBAHASAN}

\subsection{Hasil Pengukuran Online}

Selama masa pemantauan 4 bulan telah diperoleh hampir 2000 record data yang merupakan data per jam pemantauan kualitas air intake dengan enam parameter pengukuran. 
Grafik hasil pengukuran kualitas air selama jangka waktu pengamatan ditunjukkan pada gambar-gambar grafik dalam lampiran.

- Hasil pengukuran untuk parameter temperatur air yang diamati ditunjukkan pada gambar 11. Nilai rata-rata temperatur adalah $28,26^{\circ} \mathrm{C}$ dengan temperatur maksimal $32^{\circ} \mathrm{C}$ dan temperatur minimum adalah $25,99^{\circ} \mathrm{C}$.

- Hasil pengukuran untuk parameter konduktifitas atau daya hantar listrik (DHL) ditunjukkan pada gambar 12 dengan nilai rata-rata adalah $0,2 \mathrm{mS} / \mathrm{cm}$, konduktifitas maksimum $0,29 \mathrm{mS} / \mathrm{cm}$ dan konduktifitas minimum adalah $0,1 \mathrm{mS} / \mathrm{cm}$.

- Hasil pengukuran untuk parameter jumlah zat pada terlarut atau total dissolved substance (TDS) ditunjukkan pada gambar 13 dengan nilai rata-rata adalah $0,13 \mathrm{~g} / \mathrm{l}$, TDS maksimal $0,18 \mathrm{~g} / \mathrm{l}$ dan TDS minimal adalah 0,06 $\mathrm{g} / \mathrm{l}$.

- Hasil pengukuran untuk parameter salinitas ditunjukkan pada gambar 14 dengan nilai rata-rata adalah $0,09 \%$, salinitas maksimal $0,13 \%$ dan salinitas minimal adalah $0,04 \%$.

- Hasil pengukuran untuk parameter kandungan oksigen terlarut atau dissolved oxygen (DO) ditunjukkan pada gambar 15 dengan nilai rata-rata adalah $8,98 \mathrm{mg} / \mathrm{l}$, DO maksimal $14,39 \mathrm{mg} / \mathrm{l}$ dan DO minimal adalah $0,02 \mathrm{mg} / \mathrm{l}$.

- Hasil pengukuran untuk parameter pH ditunjukkan pada gambar 16 dengan nilai rata-rata adalah $7,13, \mathrm{pH}$ maksimal 8,29 dan $\mathrm{pH}$ minimal adalah 6,47.

Rekapitulasi nilai rata-rata, maksimal dan minimal hasil pengukuran online untuk keenam parameter pengukuran ditunjukkan pada tabel di bawah ini.

Tabel 1. Nilai Rata-rata, Maksimal dan Minimal Hasil Pengukuran Online

\begin{tabular}{|l|c|r|c|c|c|c|}
\hline \multicolumn{1}{|c|}{ Nilai } & $\begin{array}{c}\text { Suhu } \\
{ }^{\circ} \mathrm{C}\end{array}$ & $\begin{array}{c}\text { DHL } \\
\mathrm{mS} / \mathrm{cm}\end{array}$ & $\begin{array}{c}\text { TDS } \\
\mathbf{g} / \mathrm{l}\end{array}$ & $\begin{array}{c}\text { Sal } \\
\%\end{array}$ & $\begin{array}{c}\text { DO } \\
\mathrm{mg} / \mathrm{l}\end{array}$ & $\mathrm{pH}$ \\
\hline Rata-rata & 28,26 & 0,20 & 0,13 & 0,09 & 8,98 & 7,13 \\
\hline Maksimal & 32,00 & 0,29 & 0,18 & 0,13 & 14,39 & 8,29 \\
\hline Minimal & 25,99 & 0,10 & 0,06 & 0,04 & 0,02 & 6,47 \\
\hline
\end{tabular}

\subsection{Kesimpulan}

Dari hasil kegiatan pemantauan kualitas air intake PDAM Taman Kota di Cengkareng Drain menggunakan teknologi online monitoring dapat disimpulkan sebagai berikut:
- Dalam tabel data pengukuran terdapat hasil pengukuran yang menunjukkan nilai $0,00 \mathrm{di}$ semua parameter ukur. Angka ini muncul ketika pertama kali sensor dinyalakan setelah proses kegiatan perawatan dan kalibrasi. Atau ketika terjadi pemadaman listrik untuk beberapa saat.

- Kalibrasi DO menggunakan nilai 8 mg/l untuk larutan standar yang disiapkan untuk keperluan kalibrasi. Hasil pengukuran yang menunjukkan angka jauh di atas nilai standar tersebut kemungkinan menunjukkan adanya peningkatan pengoperasian blower pada reaktor biofilter.

- Hasil pengukuran DO yang menunjukkan angka jauh di bawah nilai standar mengindikasikan bahwa terjadi penutupan kotoran di permukaan sensor DO, sehingga perlu dilakukan perawatan.

- Keamanan lokasi pemantauan cukup terjamin karena berada di dalam lingkungan yang tertutup dan dijaga oleh satpam selama 24 jam, sehingga tidak perlu memasang / membuat bangunan pelindung untuk sensor dan data logger.

\subsection{Saran}

Saran yang dapat diberikan terhadap pelaksanaan kegiatan pemantuan kualitas air ini adalah sebagai berikut :

- Kondisi air yang diamati secara visual sangat keruh dan berwarna coklat. Pengukuran online kualitas yang telah dilaksanakan menggunakan sensor yang tidak memiliki probe untuk mengamati kekeruhan atau turbiditas. Sehingga untuk melengkapi data pengukuran khususnya parameter kekeruhan (turbidity) dalam satuan NTU dan jumlah zat padat tersuspensi / total suspended solid (TSS) dalam satuan ppm perlu digunakan sensor dengan spesifikasi yang memiliki probe turbidity.

- Dengan kondisi air yang sangat keruh sebaiknya kegiatan pemeliharaan dan kalibrasi sensor dilakukan lebih sering lagi, misalnya dua kali dalam sebulan.

- Untuk membandingkan hasi pengukuran oleh sensor yang digunakan dalam pengukuran online, sebaiknya diukur pula menggunakan sensor lain secara manual atau menggunakan data pembanding dari hasil analisa laboratorium.

\section{DAFTAR PUSTAKA}

1. BPLHD Jakarta, Laporan Indeks Kualitas Air Sungai di DKI Jakarta, November 2004, Provinsi DKI Jakarta 
2. PAM Lyonnaise Jaya Official Website (www.palyja.co.id), Sumber Air PALYJA, Jakarta 2009

3. PALYJA, Laporan Penelitian Peningkatan Kualitas Air Baku PDAM Taman Kota, Jakarta 2009

4. YSI Environment (2008), 6 Series Instruments and Product Quick Select Guide, www.ysi.com

5. Heru Dwi Wahjono dan Bayu Budiman (Mei 2006), Sistem Manajemen Komunikasi Data Jarak Jauh Berbasis Teknologi SMS dan Radio Telemetri Untuk Pemantauan Kualtias Air, JTL Vol 7 No. 2 Mei 2006

\section{LAMPIRAN}

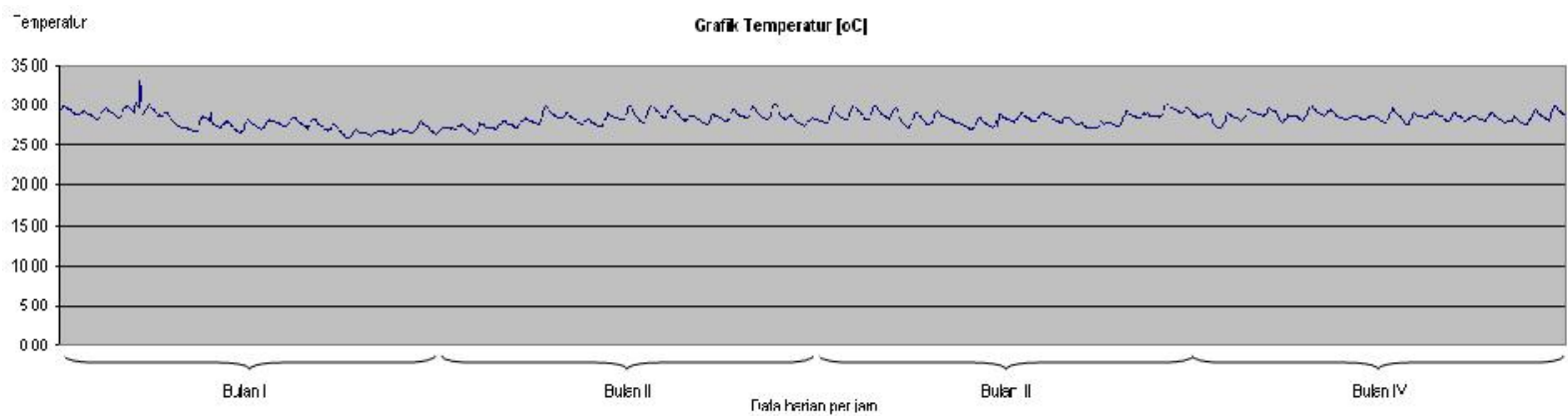

Gambar 11. Grafik Temperatur [ $\left.{ }^{\circ} \mathrm{C}\right]$

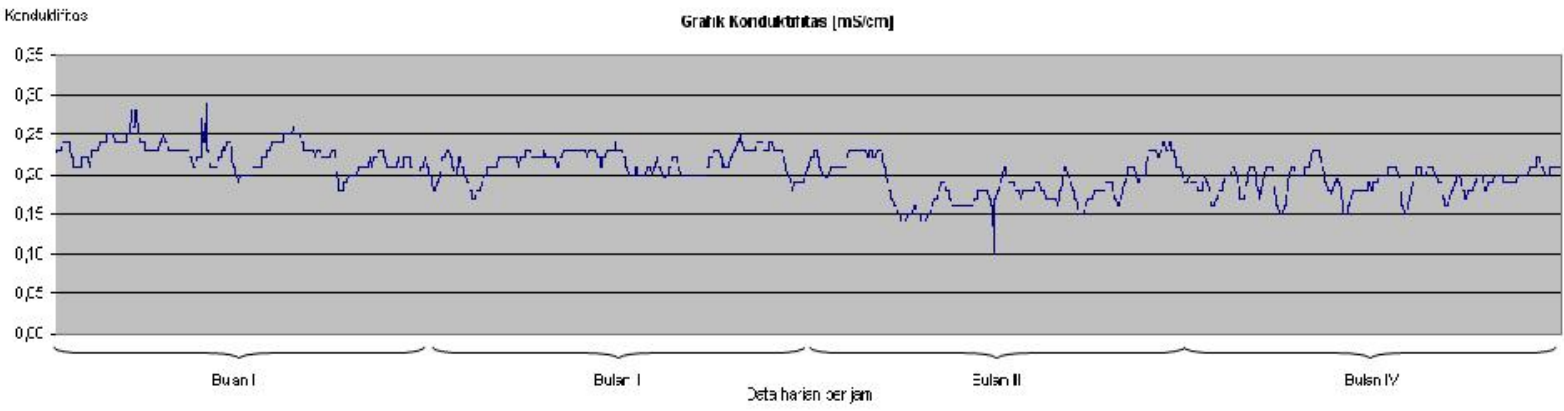

Gambar 12. Grafik Konduktifitas [mS/cm]

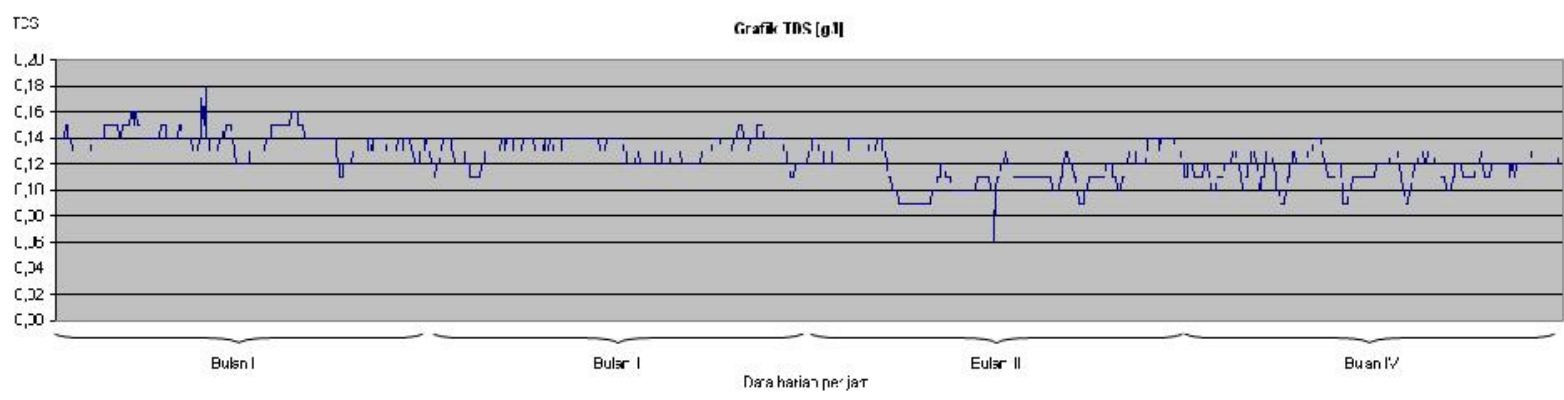

Gambar 13. Grafik TDS [g/l] 


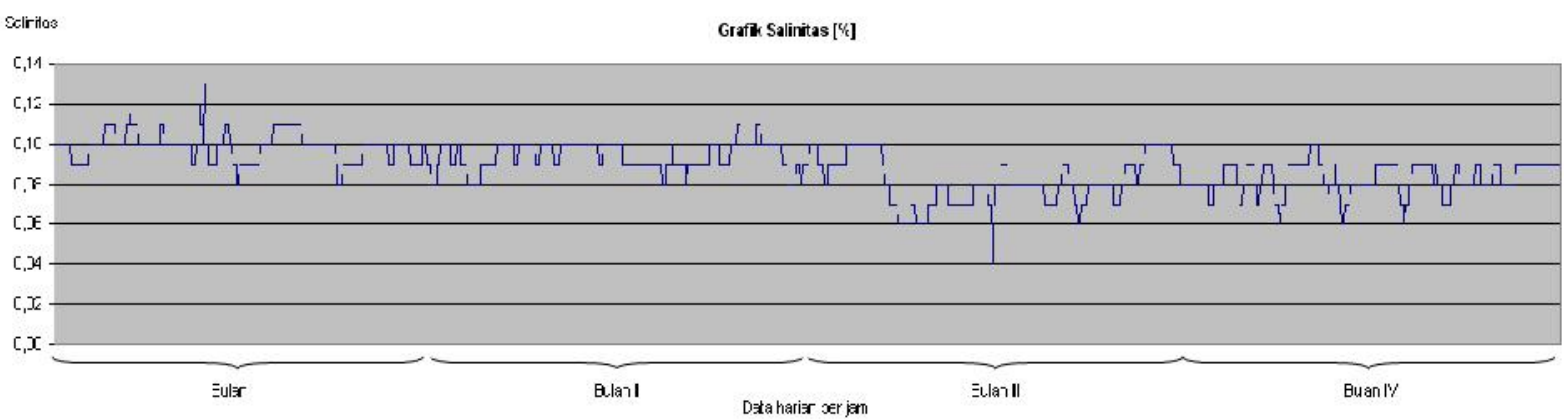

Gambar 14. Grafik Salinitas [\%]

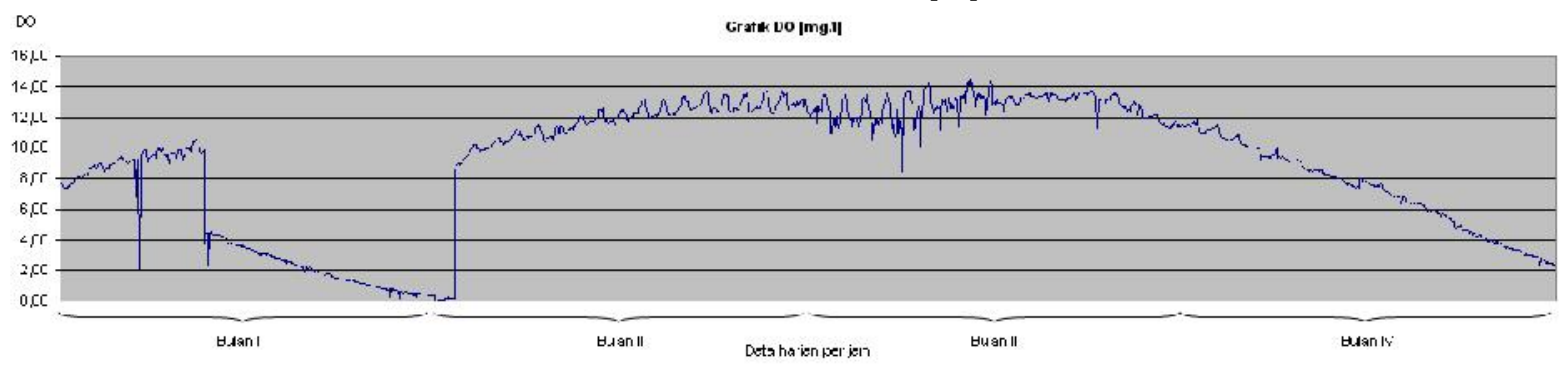

Gambar 15. Grafik DO [mg/l]

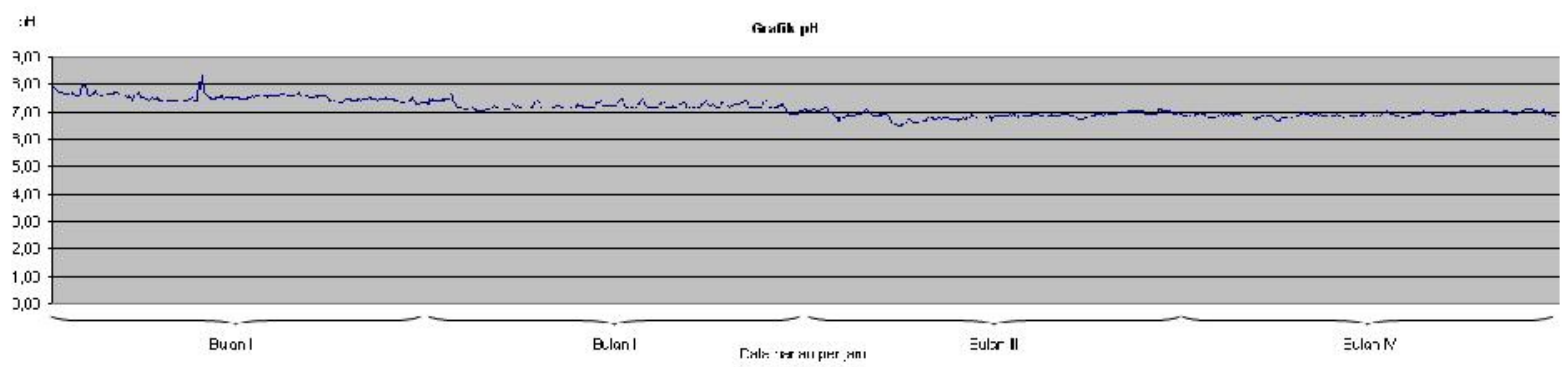

Gambar 16. Grafik pH 


\title{
Abstrak
}

Kebutuhan air bersih di kota besar sangat bergantung kepada suplai air bersih oleh PDAM. Peningkatan kebutuhan air bersih di kota besar sebanding dengan peningkatan jumlah penduduk dan industri, namun tidak sebanding dengan suplai air bersih dan kualitas air baku yang ada. PDAM telah melakukan berbagai upaya untuk meningkatkan kualitas pelayanan air bersih kepada masyarakat. Salah satunya adalah dengan memperbaiki kinerja instalasi pengolahan air yang ada. Untuk mendukung perbaikan kinerja pengolahan air tersebut dibutuhkan pemantauan kualitas air di lokasi intake yang digunakan. Tulisan ini membahas tentang pemantauan kualitas air secara online dan realtime di lokasi intake PDAM taman kota menggunakan multi probe sensor. Hasil pengamatan ini dimanfaatkan sebagai data pembanding analisa laboratorium terhadap kualitas sumber air baku intake PDAM taman kota (Cengkareng Drain).

\begin{abstract}
The need for clean water in big cities is very dependent on water supply by water companies (PDAM). The increasing demand for clean water in big cities is proportional to the increasing of number population and industry, but not comparable to the clean water supply and quality of raw water available. PDAM has made various efforts to improve the quality of clean water services to the community. One of the effort is to improve the performance of water treatment plant (WTP). To support the improvement of the performance of WTP, required water quality monitoring at the intake location in use. This paper discusses the online and realtime water quality monitoring at the water intake location using a multi-probe digital sensor and GSM technology. This observation data is used as a comparative data analysis of laboratory data on raw water source PDAM Taman Kota (Cengkareng Drain).
\end{abstract}

